\title{
Application of English Communicative Approach in English Teaching
}

\author{
Aijuan LV \\ Weifang College of Science and Technology \\ Shouguang,Shandong 262700 China
}

\begin{abstract}
The communicative approach has developed into a world-scale English teaching theories and methods into the mainstream of contemporary international English teaching movement. Since the late 1970s, the introduction of the English teaching profession in China has produced an extensive and far-reaching impact. In recent years, the communicative approach has been actively promoted in college English teaching. Under existing conditions, classroom practice is the key. However, so far the domestic Discussion on the communicative approach remains largely theoretical, some teaching practice is due to inadequate conditions or due to the pursuit of goals too high, there is hardly a success. Classroom teaching should be oriented exchange, teachers should be combined with the actual situation and create exchange opportunities for students, so that we fully embody the main role of students in English language learning. The author certainly advantages and communicative approach to teaching revelation were discussed simultaneously on the applicability of the communicative approach to classroom teaching, and there is a problem on the communicative teaching pedagogy and how to look at the communicative approach and they put forward their point of view.
\end{abstract}

Keywords- teaching and research; communicative competence; communicative approach; English teaching; learning English

\section{INTRODUCTION}

With the growing exchanges between China and the world, English has become the communicative function of the primary purpose of English teaching. So, aimed at improving students' English language ability is undoubtedly worthy of communicative approach strongly advocated. Communicative approach is in the process of improving the traditional teaching model to the fore, and it is also beyond the traditional teaching model train students of how to use certain forms of expression certain content limitations, students pay more attention to what kind of communication in the form of under what circumstances a foreign language capacity is. English teaching theory and teaching methods become the world English teaching profession and are generally forming recognized and accepted basic principles. Especially in recent years, research and development and other related disciplines linguistic theories theory make the theoretical and ideological communicative approach further enriched and improved, the basic teaching methods are becoming increasingly mature. Communicative approach since the 1970s was introduced to China, after 20 years of research and practice experts, the basic theory and ideology has become one of the mainstreams affecting our thinking and teaching methods of English teaching, the traditional English education thoughts and in our country had a profound impact on the concept. Communicative approach focusing on students' communicative competence in English has become the most accepted by my colleagues in the teaching profession. Proposed the notion of communicative competence, and it does allow us to have a correct understanding of language and language teaching. The communicative approach is reflected in the English classroom, how to implement it in order to communicate in English among students is as a priority. To exchange of two or more persons to communicate thoughts, feelings and ideas and to influence the process produce each core communicative approach. Teachers must provide opportunities for the realization of the classroom to communicate in English, and create a variety of conditions. So far in the country most of the discussion on the communicative approach still remains in theory, there are few practices in this area, due to inadequate conditions or because the target is too high, it is difficult to be successful. Therefore, we need teaching research and teaching practice in the teaching process, it is made more scientific and reality and in line with the law of the English teaching program, by using theory to guide teaching practice.

\section{THE BASIC CONCEPT OF A COMMUNICATIVE APPROACH}

\section{A. Theoretical Basis}

Sixties of last century, communicative approach was proposed dual perspective from theory and practice of teaching reflecting the functional characteristics of language teaching, communicative competence is as an important basis for the effect of a measure of students' language acquisition, which is also at the University of Communicative Approach Teaching English to follow the main reason in the prominent features of language communication, while the communicative approach is also from the language understood aspects of language and language communication and other prominent dominant position of students in the classroom, and there was the 
consolidation of the student center theory, since then, the traditional teaching mode is completely enclosed innovation, students have access to the knowledge of the language which is no longer confined to teaching theory but outside of language use and communication materials, with the continuous improvement of the communicative approach in the actual teaching process, maturity will replace the traditional mode of teaching college English teaching. From the perspective of innovative teaching theoretical point of view, the development of college English teaching mode should be more inclined to students' actual use of language ability, the development of students' practical consciousness is a shift which is also implemented in the traditional classroom teaching.

\section{B. Reason Of Communicative Approach Encountering Difficulties In Practice}

Communicative approach emphasizes the cultivation of students' communicative competence, so many people think as long as there are many types of classroom activities, as long as the students have something to say, as long as the teachers are actively involved in the whole class, it is active and effective. Students and teachers can see that relaxed communicative classroom is higher for traditional classroom requirements. Many teachers in the practical application encountered a variety of problems, and the author is one of them. Traditional teaching is often referred broadcasting teaching. The design process of teaching and learning activities, teachers' classroom materials are needed to answer the questions of the students and even teachers will be ready at the time of preparation. Teachers are generally just as the role of the microphone, scripted reading textbooks, read the translation, read the answer. The communicative approach to the requirements of the comprehensive ability of teachers is much higher than traditional teaching. First, it is higher the communicative approach to language teachers basic skills requirements. Language teachers have high organizational skills, ability to understand the discourse, quite pragmatic competence, in order to determine whether the language is used by students in proper, in the communication scene, teachers can provide better counseling services for students, also regulate the use of role models to students to establish an example.

\section{COMMUNiCATIVE APPROACH IN COLLEGE ENGLiSH} TEACHING

\section{A. Improve Student Interest In Learning, Change From Passive Learning To Active Learning}

In traditional grammar-translation method of teaching, teachers dominate the entire English class, students learn in a passive state in order to learn the knowledge and knowledge. Because of the long-term in this passive learning state, the students will feel boring, and thus lose interest in learning English, and even think that learning English is a burden. Among the communicative approach, being consistent with the students 'interest in classroom language exchange is usually sufficiently stimulate students' desire to participate, so that students move from passive recipients of knowledge of the language to the active participants. The success of the exchange students will appreciate the practical value of the return on their efforts and the knowledge gained, which will further enhance their self-confidence, stimulate their enthusiasm for learning English, so that students master the subtle English from, and achieve the purpose of communicating in English.

\section{B. Strengthen Students' Understanding And Use Of Language Structure}

In a grammar-translation method-based English teaching, students rely mainly on compulsory memory to learn some isolated vocabulary and fragmented grammar. Communicative oriented communicative approach is that student already has the knowledge and interests and social needs as the starting point, and then guide them to put what they have learned and to learn to link to the language by listening or reading material, together with others, dialogue, discussion together to solve the problem, based on the significance of expression and language structures, the overall context of discourse and understanding is correctly, so they continue to accumulate foreign language knowledge. Through repeated practice, the language materials and related knowledge become their own language, it is to achieve the degree of automation, and it is not only conducive to oral communication, and with the increase in material master the language and knowledge, enhancing the sense of language, language communicative competence has also been a corresponding increase .

\section{Improve The Students' Communicative Competence}

Many college students learning English after eight or ten years could understand English, but could not speak English, resulting in this "deaf" English phenomenon, and an important reason for this is to ignore the traditional teaching of the cultivation of students' communicative competence, and it is deviated from the language Communication the substantive principles. Communicative approach aims to develop students' communicative competence, which is characterized by the structure and function of language teaching combine. In English teaching, not only to students and other aspects of oral and written language skills, students will also utilize the English language skills of communication capabilities. Communicative approach is a language of knowledge and ideas practical activities carried out under the leadership of the teachers. In this practice, students become subject, teachers only need give arrangement of the teaching activities, students will be actively involved with to get the language and communication skills practice and improve. In the process of teaching, English teachers can be set depending on a variety of simulated communicative teaching content sites, create an authentic language environment for students, so that students improve language communicative competence. 


\section{DEVELOP COMMUNICATION CAPACITY OF STUDENTS AND LEARNING}

English teaching in college makes students difficult to communicate with teachers, and if you do not guide students to do the right communication and independent learning, student learning is difficult to achieve the desired progress. Communicative approach is a good access point, we use the communicative approach to reach students and teachers to actively communicate, learn to have self-learning ability, which will have an independent communicative competence, this is crucial. In the early launch of this model of education, we are required to actively play an exemplary role, we allow some students to learn to communicate, and then let the rest of the students to join in, so that the students will gradually adapt to this exchange of learning mode, but not to the final result of the teachers on the podium with their own exchanges. However, this mode of implementation of classroom interaction is less than half the successful teaching, teachers also need to pass a series of teaching methods, such as group discussions, role playing, scenario simulation methods such fixed linguistic background implanted to students mind, so that students have the ability to think independently, and thus inherited this language patterns to form their own new language system. In the new Universities most students are shy, not proactively communicate; which makes the teachers in the teaching process at any time is essential to encourage students to courses.

\section{BASIC PSYCHOLOGICAL PROCESSES OF COMMUNICATION}

In English teaching there is often such a situation: facing the same teaching environment, teaching methods and teaching resources, learning learners will be very different, the causes of these differences are many, there are genetic differences between individuals, families background differences, cognitive style differences, differences in information processing methods as well as differences in cognitive mental processes, etc., which can be said to be caused by differences in cognitive psychology and learning process different major factor, which is an important internal factors affecting communicative effects under the same conditions and this is what we vaguely aware of but do not have a good sort out and analyze important factor, for the effect of other factors that affect teaching mental processes are dominated by external factors in the usual teaching, so the analysis of the psychological process of communication and the effective implementation of the communicative approach will have important guiding significance.

We grasp the characteristics applied talents of standard and innovation reflecting the ability of personnel training mode, targeting qualified personnel training plus specialty applications compound talents, and to develop new training plan based on the original teaching plans, implementation new teaching methods. This training objectives stressed that emphasis should be placed on the education of students on the practical application of Ability and exercise. English communicative approach is to put the classroom as a small social groups, teaching not only allow students to gain experience of the social role of communication activities in the language, also increased opportunities for students to use the language in communicative language environment, communication of teaching process, students are not only those who practice proactive activities, or social factors that affect one of the functions of discourse practice, on this basis, the student subjective ideas, attitudes, emotions, culture, etc. will affect the choice of language form and using language function, it can adapt to the needs of future jobs.

\section{CONCLUSIONS}

In order to cultivate and improve the competitiveness of student employment, graduates can quickly adapt to future jobs or further studies. Students have a solid measure of professional knowledge of English in order to adapt to the development and international exchanges and cooperation in mapping technology for their smooth operations and provide a favorable environment protection. This paper points out some problems and deficiencies existing in the Teaching of English mapping current and desired practice recommendations, and the author hopes for engineering surveying professional training there are more qualified personnel, they can more quickly adapt to the development of society. Under the new requirements of social comprehensiveness of talent, communicative approach is a new approach which can improve the education system needs to adapt to social development, and it should receive widespread attention and be vigorously promoted. This way of teaching not only changed the role of the participants in the teaching methods and teaching process, it has also been very different. English communicative approach will improve the overall quality of college students and play an important role, and it will be trusted by more and more educators.

\section{REFERENCES}

[1] Zheng Meixia. Communicative Approach in English Teaching classroom implementation[D]. Fujian Normal University,2003.

[2] Chen Hongmei. English Communicative Approach in junior high school English Teaching [D]. Southwest Normal University,2004.

[3] Geng Xiafang. Communicative Approach in College English Teaching [J] China Education Innovation Herald, 2010,32: 43-44.

[4] Cai Lili. English Communicative Approach in junior high school English Teaching [J] English Illustrated (Advanced Edition), 2014,07: 46.

[5] Zhang Yahan. Application of Communicative Approach in high school English teaching [D]. Bohai University, 2014.

[6] Qi Fengmei. Grammar Translation Method and Communicative Approach in English Teaching Practice integrated use of [D]. China University of Petroleum,2009.

[7] Ma Wenhong. Communicative approach and its application [J] in the English Teaching of Shenyang Agricultural University (Social Science Edition), 2007,03: 424-426.

[8] Sun Man. Problems of Communicative Approach in College English Teaching [J] Chinese foreign investment, 2013,16: 327. 